\title{
Digital Tourism Business Ecosystem: Artifacts, Taxonomy and Implementation Aspects
}

\author{
Deepanjal Shrestha', Tan Wenan², Bijay Gaudel ${ }^{3}$, Neesha Rajkarnikar ${ }^{4}$, and Seung Ryul Jeong ${ }^{5}$ \\ ${ }^{1} \mathrm{PhD}$ Research Scholar, School of Computer Science and Technology, Nanjing University of Aeronautics \& Astronautics \\ Nanjing, China \\ ${ }^{2}$ Professor, School of Computer Science and Technology, Nanjing University of Aeronautics \& Astronautics \\ Nanjing, China \\ ${ }^{3}$ Graduate Student, School of Computer Science and Technology, Nanjing University of Aeronautics \& Astronautics \\ Nanjing, China \\ ${ }^{4} \mathrm{PhD}$ Research Scholar, School of New Energy Science and Engineering, Nanjing Tech University \\ Pukou, Nanjing, China \\ ${ }^{5}$ Professor, Graduate School of Business IT, Kookmin University, \\ Seoul, South Korea \\ Correspondence should be addressed to Deepanjal Shrestha; deepanjal@ pusob.edu.np
}

Copyright (C) 2021 Deepanjal et al. This is an open-access article distributed under the Creative Commons Attribution License, which permits unrestricted use, distribution, and reproduction in any medium, provided the original work is properly cited.

\begin{abstract}
Digitalization and inter-connectedness of business systems have increased the dependency between business entities. The ever-changing environment and business demands have increased competition and collaboration among diverse entities, which have forced the concept of ecosystem models. This work highlights the need for a digital tourism business ecosystem model for the tourism industry of Nepal. The work is built on interviews with experts from the Nepal tourism sector and the study of literature, reports, and publications in the field of tourism and digitalization in tourism of Nepal. Interviews are carried out on a one-to-one basis with 30 selected industry experts as a source of information and data. The study builds a taxonomy of different scenarios of tourism, a conceptual model for the Digital Tourism Business Ecosystem, and an Implementation model for Nepal. Further, as the selection of resources is a crucial factor in Digital Business Ecosystem, an Analytical hierarchical processing model is proposed as a solution for resource selection and optimization. This work is important as it brings out the need for a Digital Tourism Business Ecosystem in today's context, especially for the tourism industry. Secondly, it demonstrates the practical aspects of the Digital Tourism Business Ecosystem Model for Nepal. The work can further serve as a reference and knowledge base for digital business system analysts, system designers, and digital tourism business implementers for better digital business system designs and implementation in the tourism sector.
\end{abstract}

KEYWORDS- Digitalization, digital ecosystem, digital species, integrated systems, taxonomy, Nepal tourism

\section{INTRODUCTION}

The advent of Information and Communication Technology (ICT) has brought massive changes to almost all sectors of human endeavor in the last 20 years [1]. There is no field of research or application that has not been affected by ICT. Business organizations have experienced a massive change with ICT and this has given rise to new forms of business, new boundaries, and new opportunities extending the spheres of business from domestic to global markets [2]. The technology has empowered big enterprises, SMEs, and independent ones by integrating them in a chain of interrelated and inter-dependent components [2]. The tourism industry is one of the leading examples that depict the true impact of ICT on business. The rise of different technologies, tools, social applications, sensor networks, mobility systems, augmented reality and computing paradigms have reinforced a new digital value in business scenarios [3]. The expanding digital value sphere challenges the current business models and requires future business models to address technological advancements and changes.

Digital Business Ecosystem or DBE is the answer that addresses the growing complexity of technological advancement and developments. The DBE relates to a system that is a distributed, adaptive, open socio-technical system with properties of self-organization, scalability, and sustainability inspired by natural ecosystems [4] as shown in figure 1. They have been considered highly relevant especially in the case of clustered and fragmented sectors where a good number of Small and Medium Enterprises are operating, as it is in the case of tourism [4]. Further, the current research scenario has also shown that underdeveloped and developing nations have an immense scope to utilize the power of ICT to empower themselves and witness short-term and long-term growth [6]. The application of ICT becomes vital for landlocked and small 
countries like Nepal to promote growth opportunities and reduce the digital divide [7]. Tourism is one of the most significant areas to look at, as it is the second biggest industry of Nepal and contributes as the second industry to the Nepalese economy.

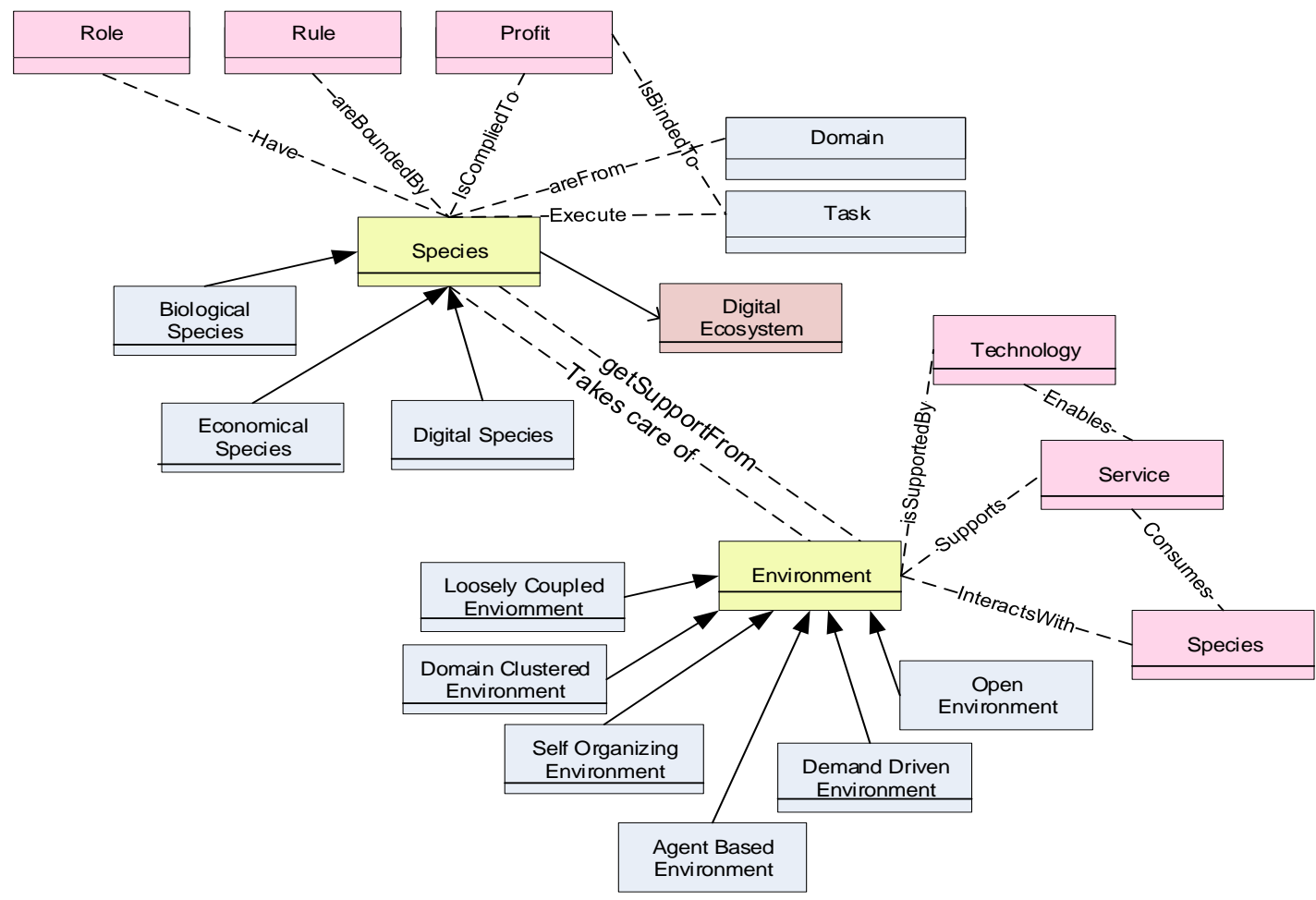

Fig. 1: Digital Business Ecosystem Concepts. Ref [5]

The tourism industry has witnessed growth with a rising number of tourists as shown in fig 2 which holds a lot of scope for business in the coming days. The geographical diversity, rich culture, growth in the ICT sector, accountable penetration of mobile and data networks makes Nepal a good source of research for understanding the role of ICT and implementing ICT-related systems and services [8] [9]. The use of technology to cater to current needs and provide sustainability, in the long run, needs the implementation to be in the form of a Digital Business Ecosystem.

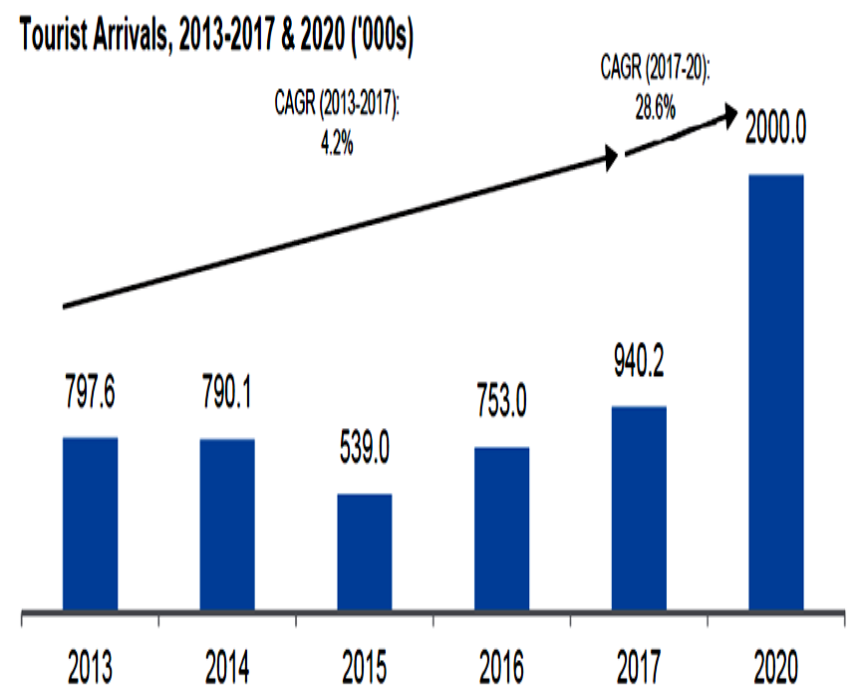

Fig. 2: Tourist arrival rate representation from 2013-2020 based on tourist statistics published in the year 2020 [9]

\section{DIGITAL TOURISM BUSINESS ECOSYSTEM}

A digital business ecosystem is an interdependent group of enterprises, people, and/or things that share standardized digital platforms for a mutually beneficial purpose, such as commercial gain, innovation, or common interest [10]. Digital ecosystems enable you to interact with customers, partners, adjacent industries - and even your competition." These systems have come up as a new area of research and many business organizations like SMEs are adopting this model to find sustainability in their businesses. An investigation of the various components of the digital ecosystem serves as an important base for the construction of the Digital Tourism Business Ecosystem Model (DTBEM). Digital Business Ecosystems were triggered as an initiative, Go Digital, aimed at boosting ICT adoption by European SMEs [11]. It is generally thought that ICT is one of the major contributors to economic growth and economic efficiency. "ICTs are central to boosting productivity and improving competitiveness"; "Public and private information and communication technologies contributed nearly $50 \%$ of EU productivity growth between 2000 and 2004 [11]. The synthesis of the concept of Digital Business Ecosystem emerged in 2002 by adding "digital" in front of Moore's (1996) "business ecosystem" in the Unit ICT for Business of the Directorate General Information Society of the European Commission [12].

Digital Business Ecosystems are known for digital value creation, which depends on the community, complementors, competitors, and customers. Interconnection of these concepts and exchange of information decides the value of the information generated in the digital environment. The literature and research documents show that the future 
organization will be influenced by customer experience, continuous sense, responsive environment, and value creation through distribution. These systems will serve as a game-changer for business enterprises as shown in figure 3. The strong relationship existing between ICTs and tourism leads almost naturally to considering a tourism system as an integrated ensemble in which both a real physical component (the companies and organizations active in the field) and a virtual one (the digital representations of the physical elements) act in a strongly coupled way. ICTs empower consumers to identify, customize and purchase tourism products and support the globalization of the industry by providing "information of needs" to develop, manage and distribute offerings worldwide. The increasing use of ICTs plays a critical role in the competitiveness of tourism organizations and destinations [13]. The DBE is a proposed methodology for economic and technological innovation. Specifically, the DBE is an infrastructure that supports large numbers of interacting business users and services [14]. It aims to be a next-generation ICT that will extend the SOA concept automatically combining available and applicable services in a scalable architecture, to meet business user requests and facilitate business processes [14].

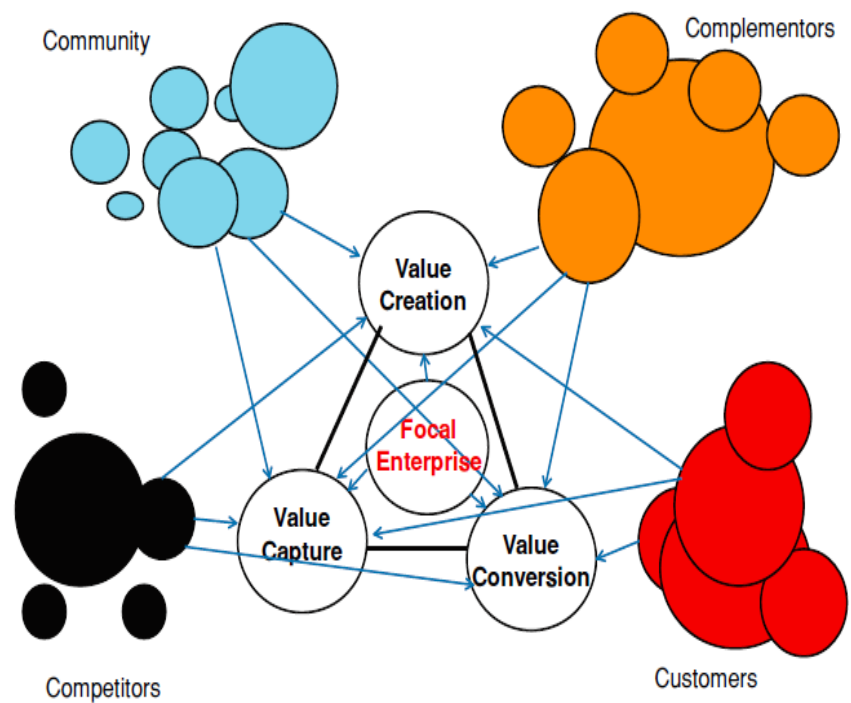

Fig. 3: Value Map of Digital Business Ecosystem. Ref [11]

Digital Business Ecosystems are made possible by the convergence of three networks: ICT networks, Social networks, and Knowledge networks. The networked connections enabled by the Internet and the WWW grew along with the links of the pre-existing and underlying social, professional, and business networks between governments, researchers, businesses, and companies to coin the powerful concept [15]. These systems have evolved as a mature discipline of scientific literature to describe business-oriented socio-technical systems regardless of their location and structure. [15]. Thus any future implementation of ICT must be in terms of Digital Ecosystems to be sustainable.

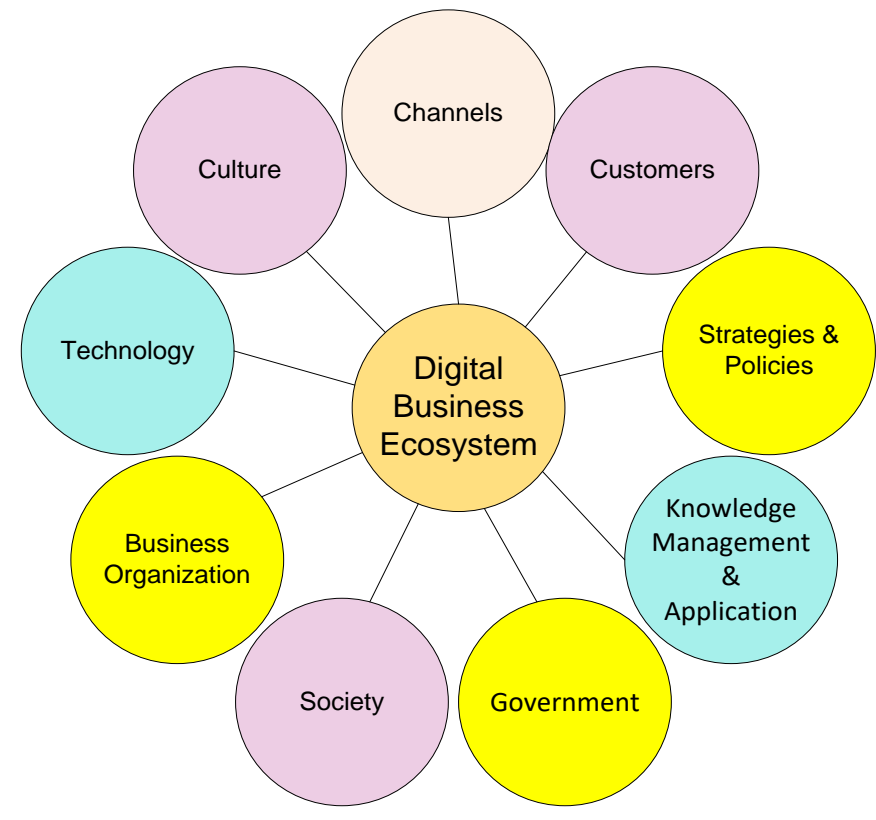

Fig. 4: Digital Business Ecosystem Inter-Dependent Components. Ref [15]

Figure 4 depicts artifacts of a digital business ecosystem that is based on the Gartner research group and is modified to include other artifacts of the digital business ecosystem based on literature and work of other scholars as shown. The model has 8 dimensions that form an integral part of the system. The described components form an integral part of the system and are very important for the execution and survival of the Digital Business Ecosystem. Culture, society, and customers form the basis of social computing whereas technology, knowledge management, and channels serve as infrastructure and medium of transfer and communication and business organization, government, and strategies and policies make up important components of the business environment for the tourism business. Similarly, table 1 shows some of the renowned work in the area of Digital Business Ecosystem in the current scenario.

Table 1: Studies on Digital Business Ecosystem

\begin{tabular}{|c|c|c|c|}
\hline $\begin{array}{l}\text { Publisher } \\
\text { and Date }\end{array}$ & Title & $\begin{array}{c}\text { Study } \\
\text { component }\end{array}$ & Ref \\
\hline $\begin{array}{l}\text { IEEE, } \\
\text { Conference } \\
\text { Series, 2008 }\end{array}$ & $\begin{array}{l}\text { Ontological } \\
\text { framework for trust } \\
\& \text { reputation for DBE }\end{array}$ & $\begin{array}{l}\text { Feedback ontology } \\
\text { for trust and } \\
\text { reputation }\end{array}$ & [16] \\
\hline $\begin{array}{l}\text { IEEE } \\
\text { Conference on } \\
\text { Series, } 2008\end{array}$ & $\begin{array}{l}\text { Application of } \\
\text { Digital Ecosystems } \\
\text { in the health domain }\end{array}$ & $\begin{array}{l}\text { DES design } \\
\text { methodology and } \\
\text { factors associated }\end{array}$ & [17] \\
\hline $\begin{array}{l}\text { IEEE } \\
\text { Transactions on } \\
\text { Systems, Man, } \\
\text { and } \\
\text { Cybernetics, } \\
2010\end{array}$ & $\begin{array}{l}\text { Application of } \\
\text { Digital Ecosystem } \\
\text { Design Methodology } \\
\text { Within the Health } \\
\text { Domain }\end{array}$ & $\begin{array}{l}\text { Design of DHES for } \\
\text { electronic records } \\
\text { and management }\end{array}$ & [18] \\
\hline $\begin{array}{l}\text { IEEE } \\
\text { Transactions on } \\
\text { Industrial } \\
\text { Electronics, } \\
2011\end{array}$ & $\begin{array}{l}\text { A Service Search } \\
\text { Engine for the } \\
\text { Industrial Digital } \\
\text { Ecosystems }\end{array}$ & $\begin{array}{l}\text { Design a conceptual } \\
\text { framework of a } \\
\text { service-ontology- } \\
\text { based semantic } \\
\text { service search } \\
\text { engine }\end{array}$ & [19] \\
\hline $\begin{array}{l}\text { Springer, } \\
\text { Lecture Notes } \\
\text { in Computer } \\
\text { Science, } 2014 \\
\end{array}$ & $\begin{array}{l}\text { Transformation of } \\
\text { Digital Ecosystems: } \\
\text { The Case of Digital } \\
\text { Payments }\end{array}$ & $\begin{array}{l}\text { Digital payment } \\
\text { systems as digital } \\
\text { ecosystems }\end{array}$ & [20] \\
\hline $\begin{array}{l}\text { Springer, } \\
\text { Information and }\end{array}$ & $\begin{array}{l}\text { Digital ecosystems } \\
\text { and their implications }\end{array}$ & $\begin{array}{l}\text { Importance of } \\
\text { digital ecosystems }\end{array}$ & [21] \\
\hline
\end{tabular}




\begin{tabular}{|c|c|c|c|}
\hline $\begin{array}{l}\text { Communication } \\
\text { Technologies in } \\
\text { Tourism, } 2021\end{array}$ & $\begin{array}{l}\text { for competitive } \\
\text { strategy }\end{array}$ & $\begin{array}{l}\text { and their } \\
\text { advantages }\end{array}$ & \\
\hline $\begin{array}{l}\text { Emerald, } \\
\text { International } \\
\text { Journal of } \\
\text { Tourism Cities, } \\
2020\end{array}$ & $\begin{array}{l}\text { New digital tourism } \\
\text { ecosystem: } \\
\text { understanding the } \\
\text { relationship between } \\
\text { information sources } \\
\text { and sharing economy } \\
\text { platforms }\end{array}$ & $\begin{array}{l}\text { Study of } \\
\text { relationship } \\
\text { between the use of } \\
\text { traditional } \\
\text { operators, online } \\
\text { travel agencies }\end{array}$ & [22] \\
\hline $\begin{array}{l}\text { Science Direct, } \\
\text { Journal of } \\
\text { Hospitality and } \\
\text { Tourism } \\
\text { Management, } \\
2020\end{array}$ & $\begin{array}{l}\text { A boundary objects } \\
\text { view of } \\
\text { Entrepreneurial } \\
\text { Ecosystems in } \\
\text { tourism }\end{array}$ & $\begin{array}{l}\text { Conceptualization } \\
\text { of Entrepreneurial } \\
\text { Ecosystems (EEs) } \\
\text { in tourism }\end{array}$ & [23] \\
\hline $\begin{array}{l}\text { MDPI, Land } \\
\text { Journal, } 2018\end{array}$ & $\begin{array}{l}\text { The Role of Tourism } \\
\text { in the Ecosystem } \\
\text { Services Framework }\end{array}$ & $\begin{array}{l}\text { Ecosystem Service } \\
\text { Framework and role } \\
\text { of tourism in it }\end{array}$ & [24] \\
\hline
\end{tabular}

\section{TECHNOLOGICAL DEVELOPMENTS IN NEPAL}

The development of ICT in Nepal started with the establishment of Nepal Doorsanchar Company - a government-owned entity established in early 1913 [25]. In 1980 the digital exchange system was established making telecom services available to the general public. The major technological breakthroughs of Nepal are listed in table 2. The ICT development of Nepal was not up to the mark till 2005 and it is seen that from 2005 onwards the government of Nepal has concentrated its direction on the development of ICT [25] [26]. Currently, the country has introduced all the latest technological innovations in the sector of communication with a mobile penetration rate of $113 \%$ in 2017 and an internet penetration rate of $57 \%$ in 2017 shown in fig. 5 and 6 [26]. Further, the social site statistics show that Nepal has 24\% active users with Facebook 91.03\%, YouTube $5.52 \%$, Twitter $1.15 \%$, Pinterest $0.91 \%$, LinkedIn $0.61 \%$, Instagram $0.35 \%$. The current ICT scenario of Nepal looks acceptable and the ICT services can be extensible used with effective planning in the Tourism Industry of Nepal [27] [28].

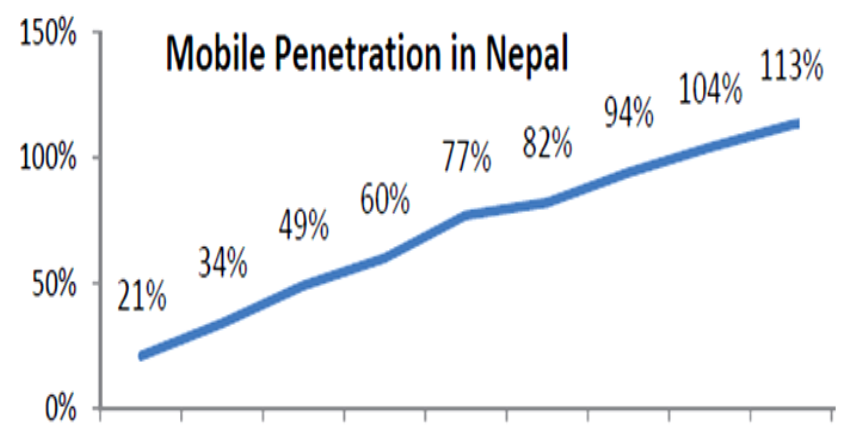

$\begin{array}{lllllllll}2009 & 2010 & 2011 & 2012 & 2013 & 2014 & 2015 & 2016 & 2017\end{array}$

Fig. 5: Statistical data representing mobile penetration in Nepal [27]

The ICT scenario has slowly started developing in Nepal and there are immense research and development opportunities that need to be customized for Nepalese tourism and the business environment. Many notable scholars have worked to study the scope and application of digitalization in Nepal. Scholars like Anup Shrestha worked on E-tourism adoption model for Nepal [29], Bidur Devkota covered the area of use of tweets in tourism [30], Shrestha and Jeong worked to propose an ICT framework for tourism [31], and Tan and Shrestha worked towards sustainable tourism in Nepal [32] have greatly emphasized the role of ICT in the Nepalese tourism industry. The abruptly growing digital use and electronic payment system will challenge the current digital system and the need to move and conceptualize DBE will be mandatory.

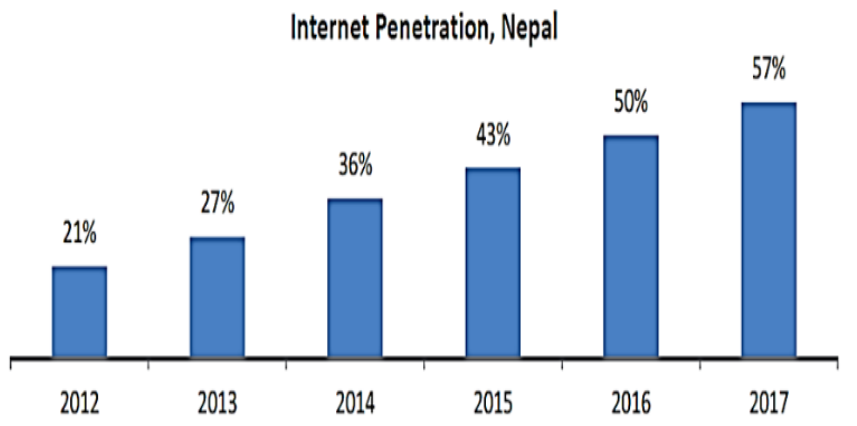

Fig. 6: Data regarding Internet penetration in Nepal [27]

Table 2: ICT Development in Nepal [25][26][27]

\begin{tabular}{lc}
\hline & STAGES OF ICT DEVELOPMENT IN NEPAL \\
\hline $\mathbf{1 9 1 3}$ & Nepal Doorsanchar Company \\
\hline $\mathbf{1 9 7 1}$ & Introduction of computer in the country for census (IBM 1401) \\
\hline $\mathbf{1 9 7 4}$ & Establishment of the Electronic Data Processing Center \\
\hline $\mathbf{1 9 8 0}$ & Digital Exchange System \\
\hline $\mathbf{1 9 9 2}$ & Distribution of Personal Computers in Nepal \\
\hline $\mathbf{1 9 9 6}$ & Establishment of the Ministry of Science \& Technology \\
\hline $\mathbf{1 9 9 8}$ & Telecommunications Act 1997 and Regulation \\
\hline $\mathbf{1 9 9 8}$ & Establishment of Nepal Telecoms Authority (NTA) \\
\hline $\mathbf{2 0 0 1}$ & Announcement of the first IT policy, "IT Policy 2000" \\
\hline $\mathbf{2 0 0 2}$ & Establishment of the National Information Technology Center \\
\hline $\mathbf{2 0 0 3}$ & e-Banking by Kumari Bank \\
\hline $\mathbf{2 0 0 4}$ & GSM and CDMA services. Formation of HLCIT \\
\hline $\mathbf{2 0 0 4}$ & Telecommunication Policy 2004 \\
\hline $\mathbf{2 0 0 6}$ & Electronic Transaction ordinance 2004 \\
\hline $\mathbf{2 0 0 7}$ & Electronic Transaction Act Oct, 2006 \\
\hline $\mathbf{2 0 0 9}$ & 3 G Network and Data Services \\
\hline $\mathbf{2 0 1 0}$ & Mobile wallet by e-Sewa \\
\hline $\mathbf{2 0 1 2}$ & Announcement of IT Policy 2067 \\
\hline $\mathbf{2 0 1 7}$ & Mobile Banking \\
\hline $\mathbf{2 0 1 8}$ & 4 G Mobile Network Service \\
\hline
\end{tabular}

\section{DIGITAL TOURISM BUSINESS ECOSYSTEM: ANALYSIS AND DESIGN}

Digital Tourism Business Ecosystem is a new field of study and this has limited the availability of standard tools and technologies for the development and analysis of the system in it. To work and analyses DTBE for Nepal, UML as a language is taken as a tool to represent the analysis and design artifacts of the system under consideration. 
Table 3: Profile of Respondents Interviewed

\begin{tabular}{|c|c|c|c|}
\hline Position & Sector & Major responsibility & Number \\
\hline IT Director & $\begin{array}{c}\text { Ministry of } \\
\text { Finance }\end{array}$ & Governance & 1 \\
\hline Engineer & MoCTCA & Governance & 3 \\
\hline Officer & State Tourism & Governance & 3 \\
\hline MD & Hotel & $\begin{array}{c}\text { Plan, promote, regulate, } \\
\text { administer business }\end{array}$ & 5 \\
\hline Proprietors & Travel \& & $\begin{array}{c}\text { Promote, administer and } \\
\text { manage }\end{array}$ & 3 \\
\hline ED & Trearism & Arrange, administer and manage & 2 \\
\hline IT Officers & Bank & $\begin{array}{c}\text { Manage and Administer IT } \\
\text { operations }\end{array}$ & \\
\hline
\end{tabular}

Further, to model resource optimization and selection for DTBE, Analytical Hierarchical Processing (AHP) is proposed. The study is built by interviewing some of the selected personnel from different sectors of tourism and come up with pre-analysis artifacts. The respondents used for the study are shown in table 3.

\section{A. Tourism Governance and Business Management Scenario}

This section deals with the general tourism governance model of Nepal and its related artifacts. Figure 7 depicts a generalized architecture of tourism governance of Nepal, which includes, Ministry of Culture, Tourism, and Civil Aviation (MoCTCA) as the central entity that implements its functions through the department of tourism. Nepal tourism board is connected to MoCTCA through the department of tourism. Similarly, the hotel, travel, and trekking agencies are connected to the tourism department through their respective associations. The tourist entity is connected to the tourism ministry through the instances of these organizations that make up the hotel, travel agency, and trekking agency. This generalized architecture provides us as the base for further analysis of the Digital Tourism Business Ecosystem Model for Nepal.

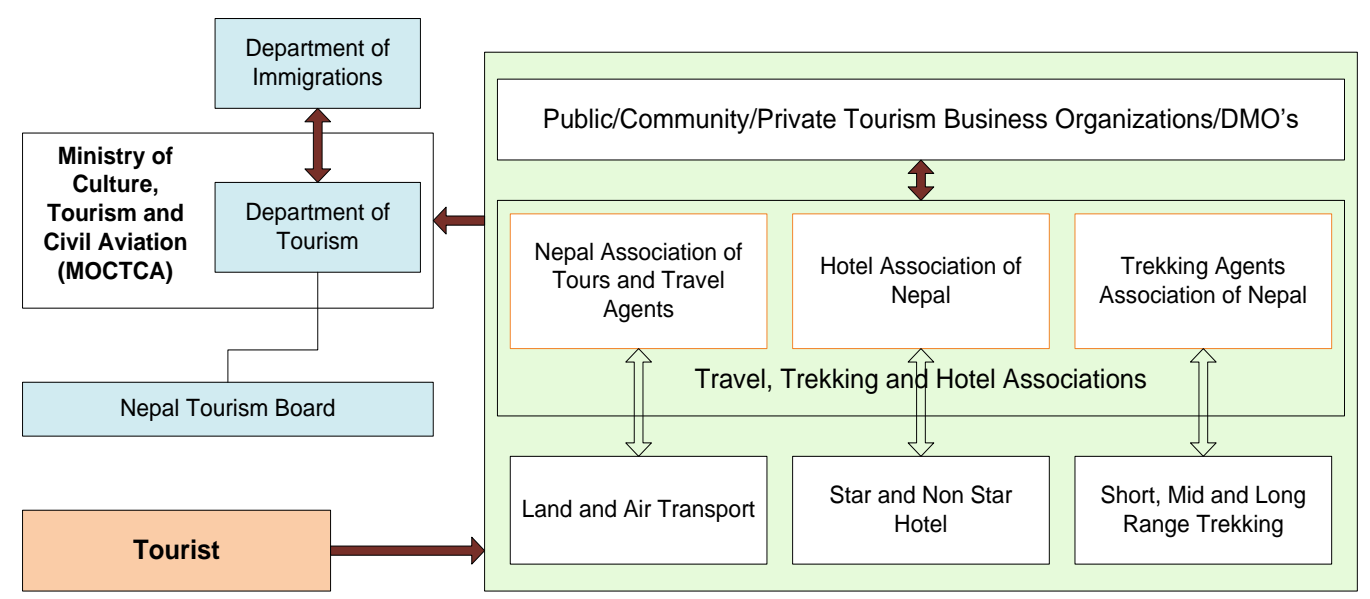

Fig. 7: Tourism Governance Architecture. Ref: [20][22][25]

\section{B. Domain Analysis}

Table 4: Problem Identification of Tourism Industry and Digitalization Scenario

\begin{tabular}{|c|l|}
\hline Area & \multicolumn{1}{|c|}{ Problem Identified } \\
\hline $\begin{array}{c}\text { Marketing \& } \\
\text { Promotion: }\end{array}$ & $\begin{array}{l}\text { Poor promotional plans and inadequate Information on } \\
\text { products, services, travel, changing market demands, } \\
\text { limited global reach, Quality vs Content }\end{array}$ \\
\hline Infrastructure: & $\begin{array}{l}\text { Poor Infrastructure, bad roads, electricity and } \\
\text { communication reach, no proper public infrastructure, lack } \\
\text { of health infrastructure, and risk mitigation scenario }\end{array}$ \\
\hline Management: & $\begin{array}{l}\text { Lack of Proper Management of Tourism Infrastructure and } \\
\text { Services. Lack of coordination between business-to- } \\
\text { business entities, government-to-business entities, Lack of } \\
\text { managing global forces and technology penetration, Lack } \\
\text { of proper regulations to manage the dynamic and growing } \\
\text { market, No cost, and quality standardization. Political } \\
\text { instability and regulatory changes. }\end{array}$ \\
\hline Health and Hygiene: & $\begin{array}{l}\text { Lack of proper information on health, hygiene, and ecology, } \\
\text { Poor quality of health services, No reach of health services } \\
\text { in remote areas. Poor drug supplies }\end{array}$ \\
\hline Risk and Mitigation: & $\begin{array}{l}\text { No proper channels and mechanisms for information } \\
\text { update in terms of natural hazards, change in biodiversity, } \\
\text { ecology, and risk mitigation, No plans to mitigate } \\
\text { emergencies and accidents occurring in the tourist sites. }\end{array}$ \\
\hline $\begin{array}{l}\text { Information } \\
\text { Availability: }\end{array}$ & $\begin{array}{l}\text { Very little data on websites/portals/books/brochures } \\
\text { regarding tourist destinations in Nepal. Fragmented } \\
\text { databases and information gaps in all sectors of Tourism. }\end{array}$ \\
\hline
\end{tabular}

\begin{tabular}{|c|c|}
\hline & $\begin{array}{l}\text { No real-time updates, repetitive and poor data quality, no } \\
\text { integration of data sources, lack of digital integration of all } \\
\text { tourism sectors at the national level }\end{array}$ \\
\hline $\begin{array}{l}\text { Communication } \\
\text { System: }\end{array}$ & $\begin{array}{l}\text { Poor internet at extreme locations, bad communication } \\
\text { system, Power shortages, poor quality of communication, } \\
\text { High cost, irregular and poor services. }\end{array}$ \\
\hline Governance: & $\begin{array}{l}\text { Poor communication channel among public/private } \\
\text { partnerships in the tourism sector. Lack of strategic vision } \\
\text { of Government in implementation of technology for } \\
\text { business. Lack of financial support, Unskilled manpower, } \\
\text { Corruption }\end{array}$ \\
\hline $\begin{array}{l}\text { Business to } \\
\text { Business: }\end{array}$ & $\begin{array}{l}\text { Competition, Lack of information sharing and proper } \\
\text { mechanism for digital integration. Public trust, cooperation } \\
\text { between private sector, local and community tourism } \\
\text { sectors. Syndicate, Poor quality plans and policies for } \\
\text { tourism. }\end{array}$ \\
\hline Human Resource: & $\begin{array}{l}\text { Lack of trained and skilled manpower in the tourist industry } \\
\text { and ICT industry, Dependency on other nations (India and } \\
\text { China), Brain drain and high cost }\end{array}$ \\
\hline Digital Access: & $\begin{array}{l}\text { No proper channels for digital payment, lack of Digital } \\
\text { payment culture, Security and privacy, transaction } \\
\text { limitation, legal issues, Integration issues in financial } \\
\text { institutions }\end{array}$ \\
\hline $\begin{array}{l}\text { Policy, Legality \& } \\
\text { Regulations }\end{array}$ & $\begin{array}{l}\text { Weak legal framework, poor tourism policies, no proper } \\
\text { mechanism for legal disputes, specially in case of digital } \\
\text { scams and cyber theft, Poor digital monitoring agency. }\end{array}$ \\
\hline Culture and Society: & $\begin{array}{l}\text { Less educated mass, mixed culture at different places, lack } \\
\text { of awareness, language barriers, social barriers based on } \\
\text { gender. No digital culture still in existance }\end{array}$ \\
\hline
\end{tabular}


The interviews, literature review, and background study indicate that the Nepal tourism industry is struggling with many problems. The problems range in all spheres starting from promoting agencies to service industries. The study indicates that even the Government of Nepal and tourism agencies have no aggressive strategic plans to uplift the tourism sector besides so much diversity and potential. The elementary requirements in terms of information on health and hygiene, places to stay, eat, and other vital information (update and access) are missing at large. The information sources like websites, web portals, tourism liaison offices, and extensions lack real-time updated information which is scattered, fragmented, and have a repetitive low quality of information. Table 4. summarizes the problems existing in the tourism sector of Nepal as shown above.

Table 5: Resolution for Tourism Industry and Digitalization Scenario

\begin{tabular}{|l|}
\hline $\begin{array}{l}\text { Formulate a policy that has ICT as the main component and revolves } \\
\text { around the tourism business }\end{array}$ \\
\hline $\begin{array}{l}\text { Prioritize security, privacy, and confidentiality as the major concern of } \\
\text { the digital economy }\end{array}$ \\
\hline $\begin{array}{l}\text { Educate the mass, provide training, workshop and promote digital } \\
\text { culture in the country }\end{array}$ \\
\hline $\begin{array}{l}\text { Build a national network of tourism industry integrating all the small } \\
\text { and big enterprises }\end{array}$ \\
\hline $\begin{array}{l}\text { Build a data center and utilize the current computing trends in AI, Social } \\
\text { computing to enrich data. }\end{array}$ \\
\hline $\begin{array}{l}\text { Develop an R\&D cell that works continuously to address growing } \\
\text { demands of data and information }\end{array}$ \\
\hline $\begin{array}{l}\text { Build a model to standardize data and information after validation and } \\
\text { verification of the sources. }\end{array}$ \\
\hline $\begin{array}{l}\text { Build infrastructure with quick data update and information on various } \\
\text { tourism issues including risk. }\end{array}$ \\
\hline $\begin{array}{l}\text { Build at least basic infrastructure like roads, health posts, } \\
\text { communication hubs, and information centers. }\end{array}$ \\
\hline $\begin{array}{l}\text { Make policies so that local businesses and government can benefit from } \\
\text { global competitors }\end{array}$ \\
\hline $\begin{array}{l}\text { Utilize the technologies to promote geographical spaces, biodiversity, } \\
\text { and ecological changes. }\end{array}$ \\
\hline $\begin{array}{l}\text { Create a special tourism management section that caters to quality and } \\
\text { risk mitigation scenarios }\end{array}$ \\
\hline $\begin{array}{l}\text { Enforce E-commerce, e-business, and mobile technology in the tourism } \\
\text { business. }\end{array}$ \\
\hline $\begin{array}{l}\text { Integrate all the fragmented databases and information clusters in the } \\
\text { national grid of tourism }\end{array}$ \\
\hline $\begin{array}{l}\text { Build technological models for addressing the change in climate, natural } \\
\text { hazards, biodiversity using active sensors technology, GPS systems, } \\
\text { communication satellites. }\end{array}$ \\
\hline $\begin{array}{l}\text { Increase the potential of electric power using hydro sources, renewable } \\
\text { sources, and backup systems } \\
\text { cities, and travel points. }\end{array}$ \\
\hline Build a strong communication network and avail high-speed data \\
\hline moild a mechanism to coordinate between all tourism entities and \\
\hline aild good roads and connect major tourism destinations, airports, \\
\hline andy
\end{tabular}

All these problems indicate that the foremost requirement of the tourism industry in Nepal is to have an Integrated Information System (IIS) that links up all the necessary industries in the tourism business and services [24]. The Integration model should encompass Federal, State, Municipal, and Rural tourism bodies along with public and private sectors. The implementation of ICT in the tourism industry is just an answer to the current needs of the business. As this industry is fast-growing around the world and there is an increase in competition and demands, a traditional ICT system will not be enough to manage the complex needs of the tourism industry. This requires a different approach of ICT that can meet the current and future demands. This can be addressed with analysis, design, and development of the Digital Tourism Business Ecosystem. Analysis of feedbacks as the initial solution for the problem is listed in table 5. DTBE model requires an identification of the artifacts of tourism (governing bodies, business and service sectors, tourism consumers, environmental entities, social entities, cultural entities, internet and communication technologies, adaptive computing models, and social knowledge models) that serve as the basic elements of the system. The next phase includes identifying the relationship, cooperation, dependency, association, and relevance of entities with one another to create a system that can be self-generating, self-producing, and self-organizing. A DTBE is a concept derived from the natural ecosystem that follows the principle of natural evolution and survival, therefore, the DTBE model for Nepal must adhere to these principles of the digital business ecosystem.

\section{Digital Tourism Business Ecosystem Models}

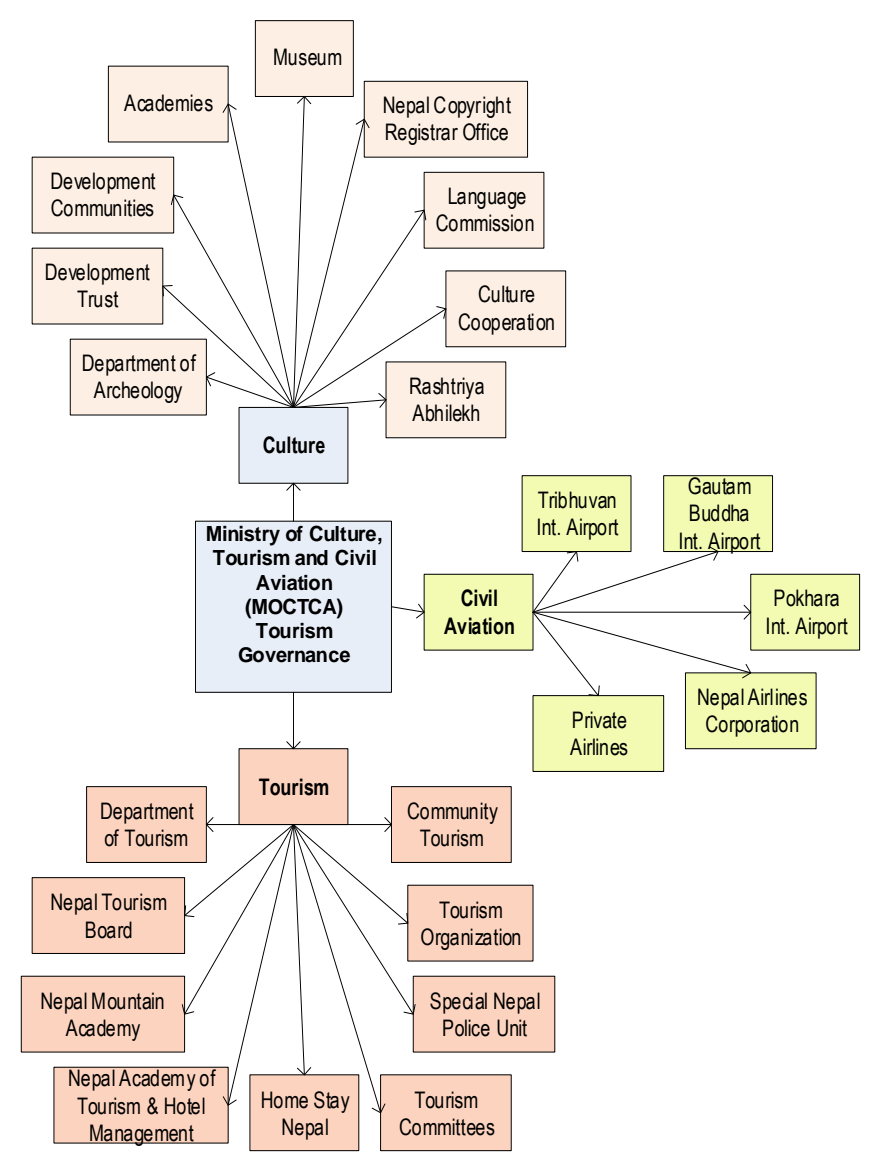

Fig. 8: Tourism Governance Taxonomy Layer 1

Building a taxonomy of concepts is a way of converting a generalized model into an equivalent digital conceptual class model of the system under consideration. Figure 8 represents the taxonomy of tourism governance of Nepal. It can be seen that MoCTCA has three important wings that include culture, tourism, and civil aviation. The culture has further had 9 sub-divisions that look at different aspects of cultural tourism and its related aspects in Nepal. Civil aviation has 5 sub-divisions that include airports, Nepal airlines cooperation, and private airline management. The tourism subdivision consists of 9 subdivisions in which the 
department of tourism is the most important division. This division is the primary body that coordinates all the other bodies. Nepal tourism board is an independent body that comes under the department of tourism and is responsible to promote and provide necessary input in the growth of tourism in Nepal. Besides these, the other divisions have their own ToR and work to develop the overall tourism of Nepal.

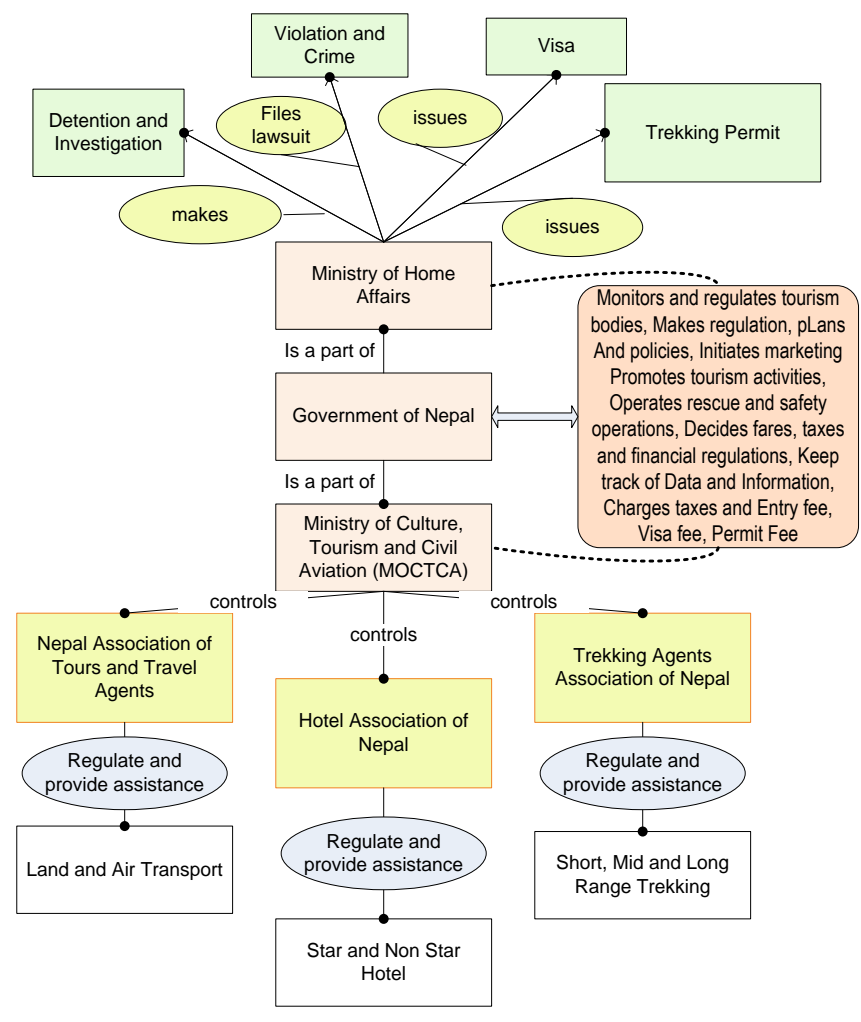

Fig. 9: Tourism Governance Taxonomy with associated Business Organizations

The Government of Nepal (GoN) is the is the apex body that is responsible to form policies, regulations and implement a strategy to promote and develop tourism in Nepal [24]. It regulates, monitors, and manages tourism-related activities through its different departments and authorized bodies. Figure 9 depicts GoN linked to MoCTCA and the Ministry of home affairs as the first entities that are responsible for the management and governance of tourism in Nepal. The Ministry of Home affairs is linked to the department of immigration that is responsible to check the validity of tourists and allow entry and exit in Nepal. Besides Visa, this body is responsible to provide trekking permits, check for immigration rules and file petitions in case some tourist violates the rules. Further, the MoCTCA is responsible to manage and look after the tourism-related activities in Nepal. The MoCTA regulates and implements its rules, regulations, and policies through different government bodies and recognized travel, hotel, and trek associations. Tourists are the central entities of the tourism business and their needs and priorities are the base of the tourism industry. The analysis of tourist data in Nepal was used to build a taxonomy of tourist relationships and needs for the tourism industry. Figure 10 depicts the relationship of tourists with 12 different entities related to tourism business and management. These entities are directly in contact with tourists in the form of product, service, or supporting entities to provide the tourist with requested service in tourism destination. Each entity has some information to share that forms the basis of tourist needs and helps tourists to make a relevant decision about a product or a service. These entities are real-world objects that are represented as equivalent concepts in the computer digital representation.

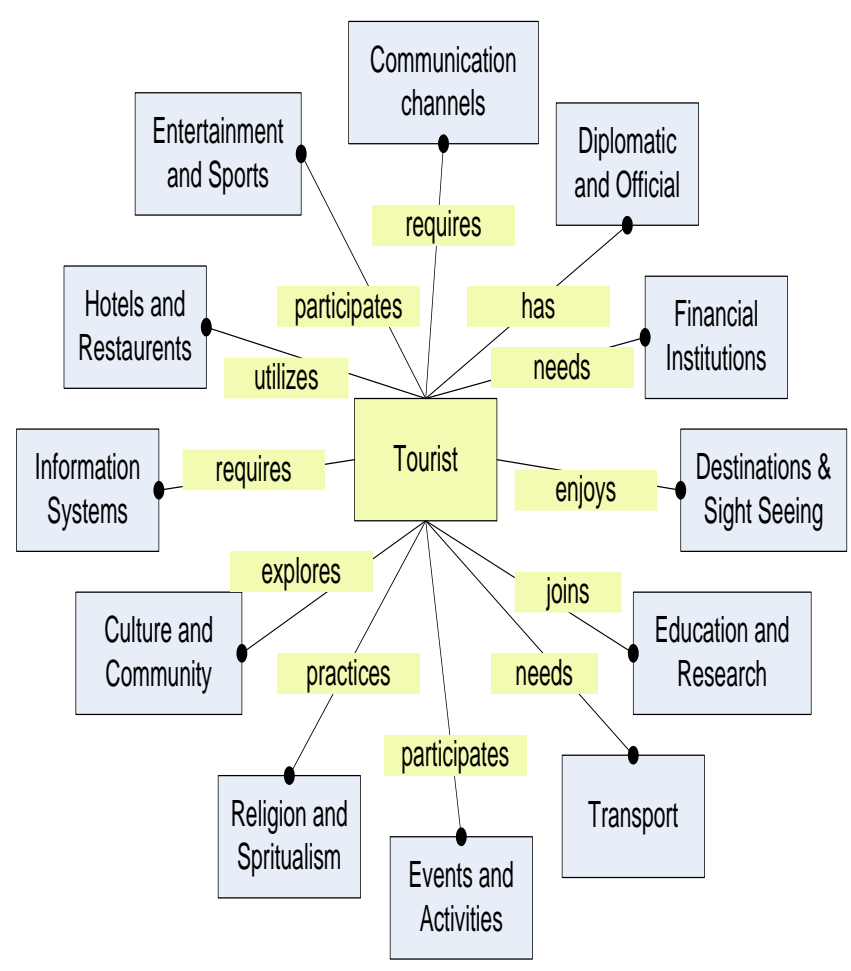

Fig. 10: Taxonomy tourism Concepts and Artifacts for Digital Tourism Business Ecosystem Model.

The changing scenario of tourism business and technological development has changed a tourist into a complex consumer who has immense power and choices for products and services in his hands [25]. Figure 11 represents a taxonomy of tourist needs and coevolution of digital technology with new digital demands in business models. As it can be seen from the figure that a new tourist has become a complex consumer with multifaceted needs and demands due to technology innovation. The needs have grown from socializing, sharing, telling stories, advertising, satisfaction measurement, to discovering and exploring places. A tourist consumer has immense reach and information to explore for better quality and price. The techno-oriented environment has created so many challenges in term of technology adoption that a business sector is unable to ignore it. The technological ability to pool services, empowered with digital media, web 2.0, and mobile technology has almost new dimensions of business and business models. There is a disruption of the traditional business model with a new form of supply chain and business models that demand interoperability, dynamic adjustment, reputation building, multichannel communication, analytical monitoring of 'tourist' Big data, and standardization. The figure below captures the tourist demands and the components that need to be addressed for the design of DTBE for Nepal. The human needs due to digitalization and changing business demands are serious aspects to look at and address in the ever evolving technological world. Those business who have ignored these changing aspects have either witnessed loss of 
market of poor growth in their business. Tourism is the most critical industry that cannot ignore these changing business dynamics as it is not only related to the local business competition but is also under constant pressure from the global competitors. It can be seen that the last few years have brought a digital boom with the integration of social sites, payment systems, big data systems, and business analytics that keeps business houses forcing to adapt to changes or lose the advantage guaranteed by these systems. Intercultural digital penetration is a big challenge that is posed by digital technologies and forces local businesses to match up to global standards. Tourists visiting from developed countries or economies look for sophisticated demands and in case these are not existing in a tourism destination, it affects the marketing value and popularity index of the destination. Hence, the implementation as a Digital Tourism Business Ecosystem is capable to force these changes in the local market as well, as the local business is also a part of the big integrated chain of digital business species. A good example of such enforced technology in Nepal is seen in the case of digital payment systems. Mobile payment systems like WeChat and Alipay were used by Chinese customers to make payments. The local business owners approached for partnership with Chinese tourism business personnel to arrange for these type of transactions as it was the need of the Chinese customer. This finally created pressure on the Government of Nepal and it allowed the local Banks and digital payment system to provide the solution for this problem. Hence, the global pressure forced the local businesses, government, and international business houses to find a solution to this problem and provide this service in Nepal. Thus proving that digital species enforce change or arrange for the change in a digital environment, which is a specialty of a Digital Business

Ecosystem

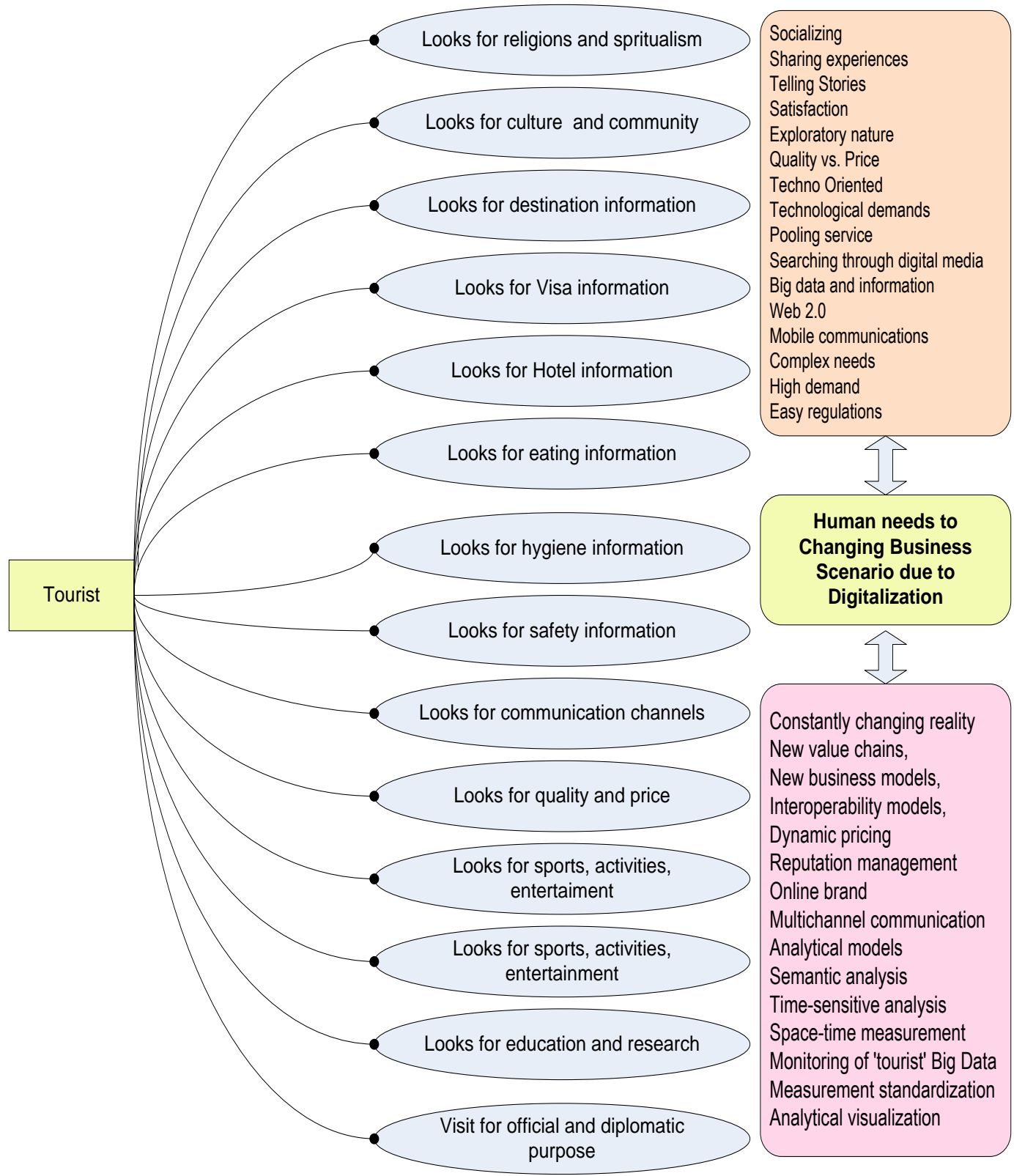

Fig. 11: Taxonomy of Tourist needs and Digital demands 

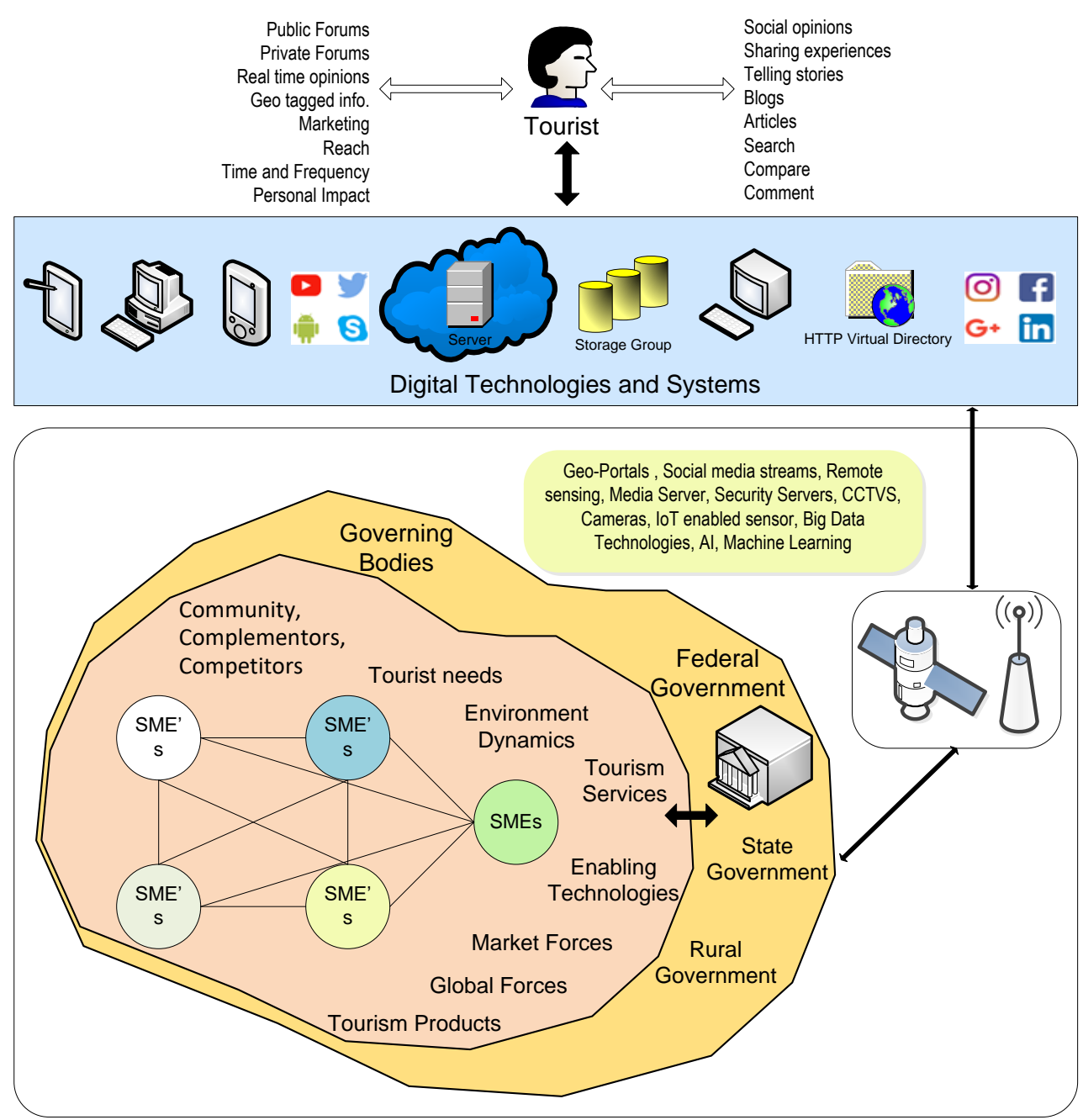

Fig. 12. Proposed Conceptual Framework of Digital Tourism Business Ecosystem

Digital Tourism Business Ecosystem Model for Nepal is a layered design process where the different levels of governance and management entities must be considered. Figure 12 proposes a Conceptual Framework for a DTBE which is shown as a layered design. The innermost layer depicts the big and small business organizations that are linked with one another through digital technology to share data and information and co-evolve with one another. This layer is populated with concepts that include community, complementors, competitors, tourist needs, environment dynamics, tourism services, enabling technologies, market forces, and global forces that make an impact on the tourism business. The business layer is the next layer, which consists of governance that controls and manages the tourism business of Nepal. This layer consists of Federal, State, Municipal, and Rural governing bodies. Coining policy, framing strategies, making laws, and monitoring the overall business of the country is on the shoulders of these bodies. The two layers are interlinked with one another and tourists through digital and communication mediums. The next layer consists of communication technologies that enable the other two layers to get connected through it.

This layer is represented as a rectangular boundary and a third layer that combines two business layers connected through communication channels and the current technologies in existence. The uppermost layer depicts enabling tools and technologies that are used by tourist and tourism business and governance entities to communicate, utilize, explore, consume, manage, govern and administer the tourism product and services. As tourist is the central entity of the tourism business, the influencing factors and attributes associated with tourist are shown in the left and right side of the tourist entity. A Digital Tourism Business Ecosystem must consider all these factors in the current business scenario to survive and take a competitive advantage in the short and long term.

\section{Digital Tourism Business Ecosystem Implementation Model}

Implementation of DTBE is a big challenge and many crucial issues need to be considered while designing, mapping, and implementing it. The first important aspect to look at is identifying the species that consume the products and services from the environment based on some rules. The participating species must belong to some domain and must play an important role in the balance of an ecosystem. In the context of tourism, a tourist is a species that belongs to a consumer class and consumes tourism products and services by paying for them and participating in them. On the other hand, the tourism service providers and tourist products are another set of species that belong to the 
producer domain and produce tourism products and services to be consumed by the species tourist. The producer class charges in favor of products and services consumed by the tourist and vice versa. In terms of DTBE, the producer class produces products and services that it advertises using digital media. The consumer identifies and books for the products and services through communication channels and digital media. The records of arrangement and schedules are all get stored in digital media and are used as a reference in the future. The consumer class tourist on a scheduled travel date uses this stored information to start with the trip and uses digital technologies to make payment, arrange for the destination, search information, and communicate at different levels. Similarly, the other species also use digital technologies and systems to track the tourist, booked products and services, monitor, track and manage his records. The travel data of a tourist in his course of journey provides feedback to the service entities to discover information patterns, travel behavior, consuming patterns, and demographic correlation. On the other hand, tourist provide feedback, share experiences, rate product and services, and make recommendations for the tourism business sector to grow, making a consumer-producer chain complete as in biological ecosystems. Figure 13 identifies the core species and environment in a distinguished domain and shows how and it way they are dependent on each other. It also elaborates on the associated digital entities that are related to the consuming and producing species forming the interwoven structure of Digital Business Entities that on the whole represent a Digital tourism business ecosystem.

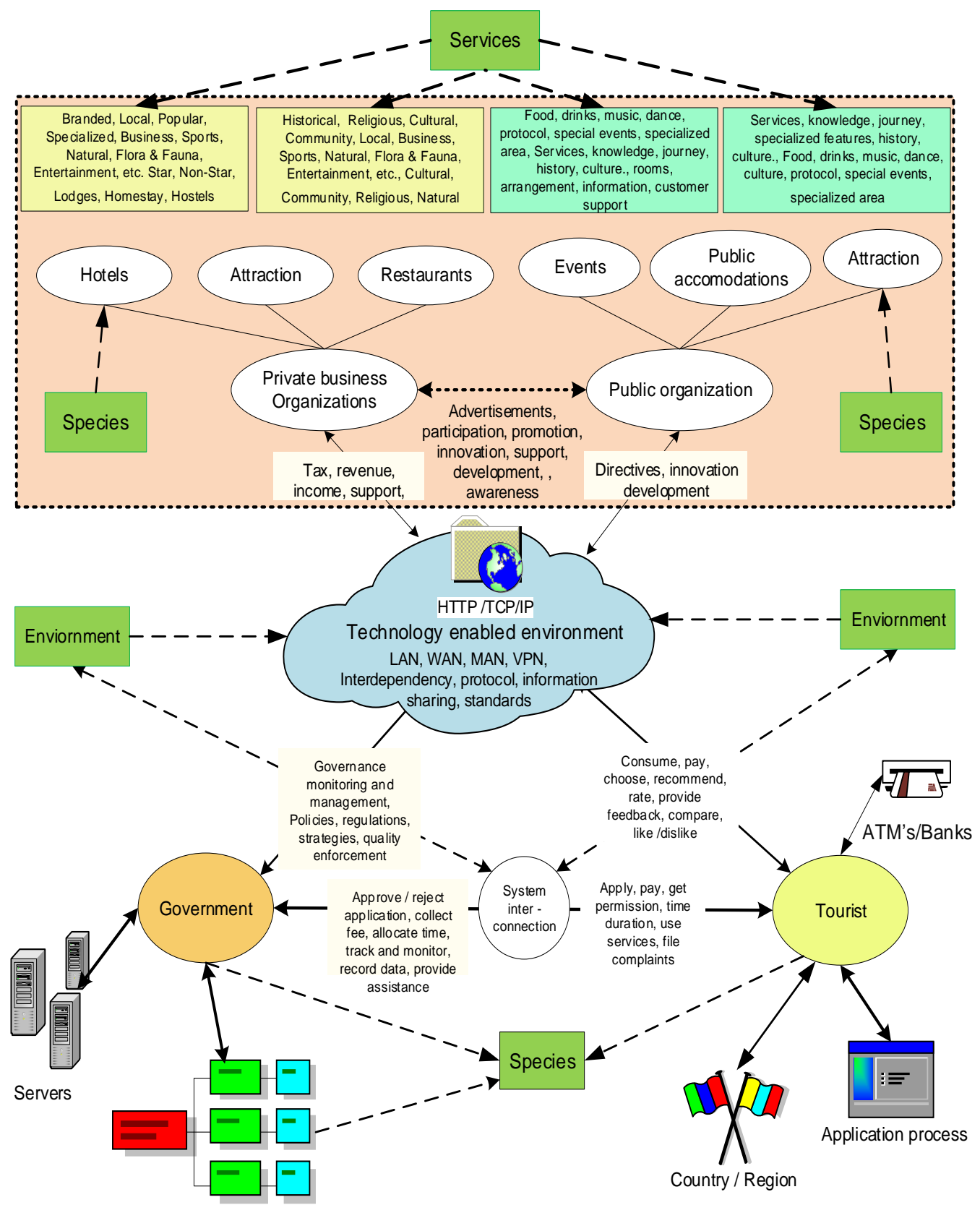

Organizational unit

Fig. 13: An Analogy and Implementation Model for Digital Tourism Business Ecosystem 


\section{E. The Resource Selection Model for DTBE}

Digital Business Ecosystems are crucial due to resource requirements. A proper analysis in terms of resource modeling is crucial to guarantee the success of an organization. Analytical Hierarchy Process Model is a good model that can help in multi-criteria decision-making regarding resource allocation. To extend our explanation of the concept we have used an example of the selection of the internet as a resource to make an optimal decision. Table 6 represents five top ISP of Nepal, which we utilize to demonstrate our concept. Table 7 represents a pairwise comparison of three criteria and table 8 represents Normalized Pair-wise Comparison Matrix.

Table 6: Representing 5 top internet service providers for Internet lease compared with three characteristics

\begin{tabular}{|l|l|l|l|}
\hline Company & Speed & Time & Amount \\
\hline World link & $60 \mathrm{Mbps}$ & 12 Months & Rs. 26,000 \\
\hline Vianet & $60 \mathrm{Mbps}$ & 13 Months & Rs. 19,140 \\
\hline Classic Tech Home & $60 \mathrm{Mbps}$ & 14 Months & Rs. 18,000 \\
\hline Subisu & $75 \mathrm{Mbps}$ & 12 Months & Rs. 22,290 \\
\hline Nepal Telcom & $55 \mathrm{Mbps}$ & 12 Months & Rs. 18,400 \\
\hline
\end{tabular}

Table 7: Pair-wise Comparison Matrix

\begin{tabular}{|l|l|l|l|}
\hline & Speed & Time & Amount \\
\hline Speed & 1.00 & 9.00 & 9.00 \\
\hline Time & 0.11 & 1.00 & 2.00 \\
\hline Amount & 0.11 & 0.50 & 1.00 \\
\hline Sum & 1.22 & 10.50 & 12.00 \\
\hline
\end{tabular}

Table 8: Normalized Pair-wise Comparison Matrix

\begin{tabular}{|l|l|l|l|l|}
\hline & Speed & Time & Amount & $\begin{array}{l}\text { Criteria } \\
\text { Weights }\end{array}$ \\
\hline Speed & 0.8182 & 0.8571 & 0.7500 & 0.8084 \\
\hline Time & 0.0909 & 0.0952 & 0.1667 & 0.1176 \\
\hline Amount & 0.0909 & 0.0476 & 0.0833 & 0.0740 \\
\hline
\end{tabular}

Table 9: Criteria and Weights

\begin{tabular}{|l|l|}
\hline Criteria & Weights \\
\hline Speed & 0.8084 \\
\hline Time & 0.1176 \\
\hline Amount & 0.0740 \\
\hline
\end{tabular}

$\lambda \max =3.0546$

Consistency Index $($ C.I. $)=(\lambda \max -n) /(n-1)$

Where $n$ is the number of compared elements $=0.0273$

Consistency Ratio = Consistency Index (C.I.) /Random

Index (R.I.), where RI for $n=3$ is 0.58

$=0.047057072<0.10 \ldots$

It can be seen from Table 9 that, since the value of Consistency Ratio (CR) is 0.047057072 for the proportion of inconsistency CR is less than 0.10 which is the standard, we can assume that our matrix is reasonably consistent. So, we may continue with the process of decision-making using AHP. Based on the requirement of the peer, these criteria weights can be used by the decision-maker for further calculation. From the table, speed has been given $80 \%$ weightage, the time has been given $11 \%$ weightage and the amount has been given $7 \%$ weightage, where speed represents the time to service, time is representing the time for which the internet lease is bought and amount describes the payable amount for buying the internet service. This model serves as a good tool to further enhance the costbenefit analysis design of digital tourism business ecosystems.

\section{F. Challenges of Digital Tourism Business Ecosystem}

The design and implementation of the Digital Tourism Business Ecosystem is a challenging task. The first challenge to the system is in terms of government regulations and policies. As these systems are interoperable, a robust policy and regulations are required to deal with any disputes at the operational or managerial level. The nature of this system is that they are dependent on one another and tightly coupled to execute any business functions, hence a robust architecture with an uninterrupted service guarantee is the most important requirement as well as poses as a challenge. Clear operational, financial, legal guidelines and privacy must be guaranteed as a primary condition between these systems to be operational. Technical support, robust architecture, resource optimization, and resource allocation are some of the other primary challenges. Besides the above issues, education, mass training, promotion, and application of digital technologies in the tourism business is a mandatory requirement for proper implementation of DTBE.

\section{CONCLUSION}

The study brings out the need for a digital business ecosystem for the tourism industry of Nepal. The work successfully demonstrates different artifacts, taxonomies, and implementation aspects of a Digital tourism business ecosystem with relevance to changing business and technology development scenarios. The study is built on one-to-one interviews of ICT and Tourism industry experts of Nepal, which makes it realistic and fit to use in the current time. The work further, practically shows the relevance of Analytical hierarchical processing as a resource selection model for critical resources and how to optimize them. The design consideration taken care of during the study makes the research a good source of knowledge for DTBE designers. Overall, the paper identifies the needs of the digital ecosystem as a technology for future digital system implementation and sustainability. The work serves as an important input for further detailed analysis, design, and development of DTBE for Nepal.

\section{CONFLICTS OF INTEREST}

The authors have no conflicts of interest to declare. The authors confirm that we have no affiliation with any organization with a direct or indirect financial interest in the subject matter discussed in the manuscript.

\section{REFERENCES}

[1] William J., Kramer, Berth Jenkins., Robert S. Ktaz, "The Role of Information and Communication Technology Sector in Expanding Economic Opportunity", Corporate Social Responsibility Initiative Report No. 22. Cambridge, MA, Kennedy School of Government, Harvard University. 2007.

[2] Wayne F. Cascio, Ramiro Montealegre. "How Technology Is 
Changing Work and Organizations", Annual Review of Organizational Psychology and Organizational Behavior, Vol. 3:349-375, March 2016, https://doi.org/10.1146/annurev-orgpsych-041015-062352.

[3] Eric Forcael, Isabella Ferrari, Alexander Opazo-Vega, Jesús Alberto Pulido-Arcas, "Construction 4.0: A Literature Review", Sustainability 2020, 12(22), 9755; https://doi.org/10.3390/su12229755

[4] Gerard Briscoe, MEDES, "Complex adaptive digital EcoSystems",'10: Proceedings of the International Conference on Management of Emergent Digital EcoSystems, October, 2010, Pages 39-46, doi.org/10.1145/1936254.1936262

[5] H. Dong, F. K. Hussain and E. Chang, "Ontology-Based Digital Ecosystem Conceptual Representation," International Conference on Autonomic and Autonomous Systems, 2007, pp. 42-42, doi: 10.1109/CONIELECOMP.2007.91

[6] A. Bethapudi. "The Role of ICT in Tourism Industry." Journal of Applied Economics and Business. VOL.1, Issue 4 - December, 2013. Andhra Pradesh. India.

[7] B.P Gautam (2007) "Opportunities and Challenges of Tourism Financing A Study on Demand and Supply; Status, Structure, Composition and Effectiveness of Tourism Financing in Nepal." Florida USA 2008. ISBN-10: 1-59942661-7.

[8] Adhikari, B. "Tourism Strategy of Nepalese Government and Tourist's Purpose of Visit in Nepal. 2011." Retrieved from aska-r.aasa.ac.jp/dspace/bitstream/10638/4985/1/0034-007201109-79-94.pdf

[9] Nepal Telecommunication Company, "MIS report 2017", Centeral Offce, Bhadrakali Plaza, Kathmandu, Nepal 2017

[10] The World Travel \& Tourism Council. (2018). WTTC Travel \& Tourism Economic Impact 2018 Nepal. London: The World Travel \& Tourism Council.

[11] Gartner, Seize the Digital Ecosystem Opportunity, Insights From the 2017 CIO Agenda Report, https://www.gartner.com/imagesrv/cio/pdf/ Gartner_CIO_Agenda_2017.pdf

[12] Laurent Probst et. al., Digital Transformation Scoreboard 2018, EU businesses go digital:Opportunities, outcomes and uptake, Publications Office of the European Union, 2018, ISBN 978-92-9202-354-6, DOI 10.2826/691861

[13] A. R. Razavi, P. J. Krause and A. Strømmen-Bakhtiar, "From business ecosystems towards digital business ecosystems," 4th IEEE International Conference on Digital Ecosystems and Technologies, Dubai, United Arab Emirates, 2010, pp. 290295, doi: 10.1109/DEST.2010.5610633.

[14] D. Shanker. "ICT and Tourism: Challenges and Opportunities. Conference on Tourism in India" Challenges Ahead, May 2008, Guwahati, India.

[15] G. Briscoe, P. De Wilde, "Digital Ecosystems: Evolving Service-Oriented Architectures", Neural and Evolutionary ComputingIn IEEE First International Conference on BioInspired Models of NETwork, Information and Computing Systems (BIONETICS) (2006), arXiv:0712.4102

[16] A. Hammadi, F. K. Hussain, E. Chang, T. S. Dillon and S. Ali, "Ontological framework for trust \& reputation for DBE," 2008 2nd IEEE International Conference on Digital Ecosystems and Technologies, 2008, pp. 650-653, doi: 10.1109/DEST.2008.4635204.

[17] M. Hadzic and T. S. Dillon, "Application of Digital Ecosystems in the health domain," 2008 2nd IEEE International Conference on Digital Ecosystems and Technologies, 2008, pp. 543-547, doi: 10.1109/DEST.2008.4635222.

[18] M. Hadzic and E. Chang, "Application of Digital Ecosystem Design Methodology Within the Health Domain," in IEEE Transactions on Systems, Man, and Cybernetics-Part A: Systems and Humans, vol. 40, no. 4, pp. 779-788, July 2010, doi: 10.1109/TSMCA.2010.2048022

[19] H. Dong, F. K. Hussain and E. Chang, "A Service Search
Engine for the Industrial Digital Ecosystems," in IEEE Transactions on Industrial Electronics, vol. 58, no. 6, pp. 2183-2196, June 2011, doi: 10.1109/TIE.2009.2031186.

[20] Henningsson S., Hedman J. (2014) Transformation of Digital Ecosystems: The Case of Digital Payments. In: Linawati, Mahendra M.S., Neuhold E.J., Tjoa A.M., You I. (eds) Information and Communication Technology. ICT-EurAsia 2014. Lecture Notes in Computer Science, vol 8407. Springer, Berlin, Heidelberg. https://doi.org/10.1007/978-3642-55032-4_5

[21] Subramaniam, M. Digital ecosystems and their implications for competitive strategy. J Org Design 9, 12 (2020) https://doi.org/10.1186/s41469-020-00073-0

[22] Schaffer N., Engert M., Sommer G., Shokoui J., Krcmar H. (2021) The Digitized Ecosystem of Tourism in Europe: Current Trends and Implications. In: Wörndl W., Koo C., Stienmetz J.L. (eds) Information and Communication Technologies in Tourism 2021. Springer, Cham. https://doi.org/10.1007/978-3-030-65785-7_34

[23] Almeida-Santana, A., David-Negre, T. and Moreno-Gil, S. (2020), "New digital tourism ecosystem: understanding the relationship between information sources and sharing economy platforms", International Journal of Tourism Cities, Vol. 6 No. 2, pp. 335-345. https://doi.org/10.1108/IJTC-092019-0173

[24] Milwood P, Maxwell A. A boundary objects view of Entrepreneurial Ecosystems in tourism, Journal of Hospitality and Tourism Management. 2020 Aug;44:243-252. PMCID: PMC7402665.

[25] Wikipedia, the free encyclopedia, "Telecommunications in Nepal", Wikimedia Foundation, Inc. March 2021.https://en.wikipedia.org/wiki/Telecommunications_in_ Nepal.

[26] Wikipedia. "Internet in Nepal". https://en.wikipedia.org/wiki/Internet_in_Nepal. Wikimedia. Foundation, Inc. January 2021.

[27] Nepal Telecommunication Company, "MIS report 2017", Centeral Offce, Bhadrakali Plaza, Kathmandu, Nepal 2017

[28] Krishana Prasain, "Social media marketing shines in Nepal market, The Kathmandu Post, April 2021, Kathmandu, Nepal, https://kathmandupost.com/money/2018/11/27/social-mediamarketing-shines-in-nepal-market

[29] Lama S., Pradhan S., Shrestha A. (2019) An e-Tourism Adoption Model \& Its Implications for Tourism Industry in Nepal. In: Pesonen J., Neidhardt J. (eds) Information and Communication Technologies in Tourism 2019. Springer, Cham. https://doi.org/10.1007/978-3-030-05940-8_23

[30] B. Devkota and H. Miyazaki, "An Exploratory Study on the Generation and Distribution of Geotagged Tweets in Nepal," 2018 IEEE 3rd International Conference on Computing, Communication and Security (ICCCS), Kathmandu, Nepal, 2018, pp. 70-76. doi: 10.1109/CCCS.2018.8586827

[31] Shrestha D., Jeong, S. R. "An ICT Framework for Tourism Industry of Nepal: Prospect and Challenges", JICS 2016. Dec.: 17(6): 113-122 http://dx.doi.org/10.7472/jksii.2016.17.6.113

[32] W. Tan, D. Shrestha and S. R. Jeong, "Digital Tourism Development and Sustainability Model for Nepal," 2019 IEEE 23rd International Conference on Computer Supported Cooperative Work in Design (CSCWD), Porto, Portugal, 2019, pp. 182-187, doi: 10.1109/CSCWD.2019.8791852. 


\section{ABOUT THE AUTHORS}
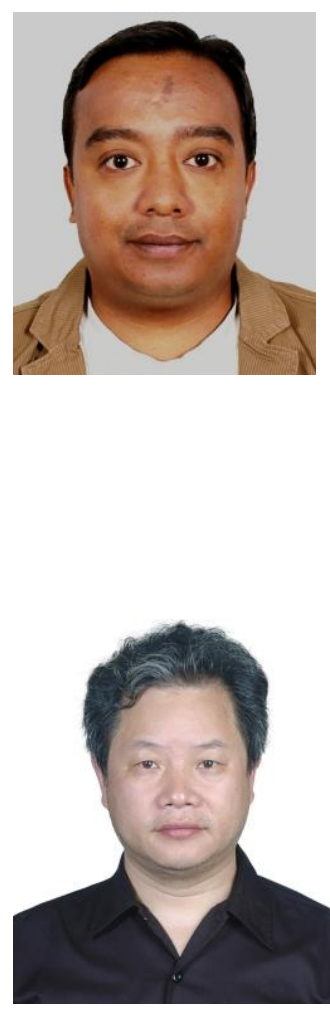

Shrestha is an Assistant Professor of MIS at Pokhara University, School of Business, Nepal. He is also a Ph.D. Scholar at Nanjing University of Aeronautics and Astronautics, School of Computer Science and Technology, Nanjing, China. He holds a Master of Science in Computer Science and a Bachelor of Computer Science Degree from Pokhara University, Nepal. His research area includes Business Ecosystems, Social Computing, Application of ICT in Business and Software Engineering.

Professor Tan Wenan is a Full Professor of Computer Science and Technology at the Nanjing University of Aeronautics and Astronautics, Nanjing, China, and Shanghai Second Polytechnic University, Shanghai, China. He holds a Master of Engineering degree in Computer Software and a $\mathrm{Ph}$.D. degree in Computer Software and Theory from Beihang University, Beijing, China. His research interest includes Software engineering, Process engineering, and development environment, Enterprise dynamic modeling, Service computing, and Enterprise intelligent information systems.

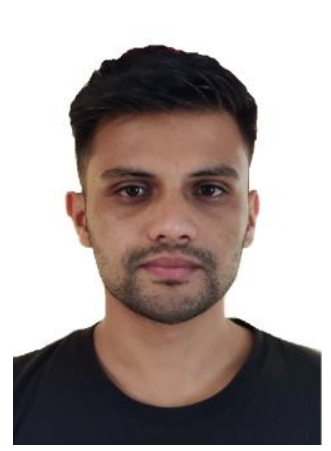

Bijay Gaudel holds a Master of Engineering Degree in Computer Science and Technology from Nanjing University of Aeronautics and Astronautics, and a Bachelor's degree in Electrical Engineering from the Institute of Engineering, Tribhuvan University, Nepal. He has done his master's degree research in Graph Representation Learning using deep learning. His research interest includes Computer vision, graph representation learning, and complex network analysis

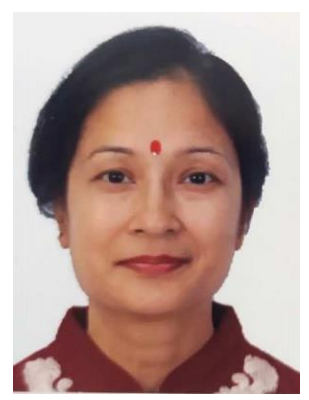

Neesha Rajkarnikar is a $\mathrm{PhD}$ Scholar at Nanjing Tech University, Department of New Energy Science \& Engineering, Nanjing, China. She has a Master's degree in Computer Applications, Masters in Gender \& Development. Her area of interest include Computer Applications, Energy Science \& Social Computing.

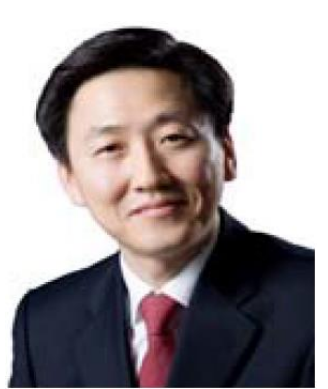

Seung Ryul Jeong is a Professor at the Graduate School of Business IT, Kookmin University, Seoul, South Korea since 1997. He earned his B.A. in Economics, from Sogang University Seoul, Korea in 1985. He completed his Master of Science degree in MIS from the University of Wisconsin - Milwaukee, WI, U.S.A., and Ph.D. in MIS from the University of South Carolina, SC, U.S.A. His research interests include System Implementation, Process Innovation, Text Mining, Project Management, Information Resource Management, and Social Computing, etc. 